\title{
Localization of Atmospherics and Their Relation to Meteorological Phenomena
}

\author{
By N. KITAGAWA, T. IIZUKA, K. MURAI \& M. KOBAYASHI
}

Geo-electric and Geo-magnetic Laboratory, Meteorological Research Institute

\begin{abstract}
We equipped cathode-ray direction-finders on three observation stations which were situated on the end-points of the long base lines, and made simultaneous recordings of atmospherics bearing on photographic fitm. With these records we located atmospherics sources over a wide region which inciudes the tropical zone.

Comparing the distribution of atmospherics sources with meteorological phenomena, we get the following results :

1. Atmospherics received stationarily in Japan are usually generated by the thunderstorms which occur in South-east Asia, Australia and India.

2. In the region to the north of the $60^{\circ} \mathrm{N}$ line, we can scarcely find the atmospherics source.

3. In the temperate region, including Japan, atmospherics are observed to be accompanied with thunderstorms frontal, lines and depressions.
\end{abstract}

Observation Methods and Equipments

The observation periods, the name of observation points and the distance among them are as follows:

1st Observation (from 12th to 18th, May, 1950)

Yonago City-Kiyose Village (in the suburbs of Tokyo) $570 \mathrm{~km}$

Yanago City-Niigata City

$580 \mathrm{~km}$

Niigata City-Kiyose Village

$250 \mathrm{~km}$

2nd Observation (from 23rd to 29th, Sep., 1950)

3rd Observation (from 12th to 19th, Jan., 1951)

Asahigawa City-Kiyose Village

$900 \mathrm{~km}$

Kiyose Village-Fukuoka City

$880 \mathrm{~km}$

Fukuoka City-Asahigawa City $1500 \mathrm{~km}$

Observations were four times a day namely at 0900, 1200, 1500, 2100 (J.S.T.) and each observation took 10 minutes. 
Main characteristics of the cathode-ray direction-finder and the method of record. ing are as follows:

Antenna: 1 meter square, 400 turn, (Effective Height $12 \mathrm{~cm}$ )

Amplifier : 3 stage straight amplifier (Gain $90 \mathrm{db}$ )

Tunning Frequency: $12 \mathrm{KC}$

Sweeping Velocity of Film: $2 \mathrm{~mm} / \mathrm{sec}$

Time Signal: J.J.Y. Standard Wave

Having gathered the records thus obtained in three respective observation points, we determined the distribution of each atmospherics source with triangulation.

Outline of the Results

One instance of the distribution of the intersection points in the 1st observation period is shown in Fig. 1. As the base line between Kiyose Village and Niigata

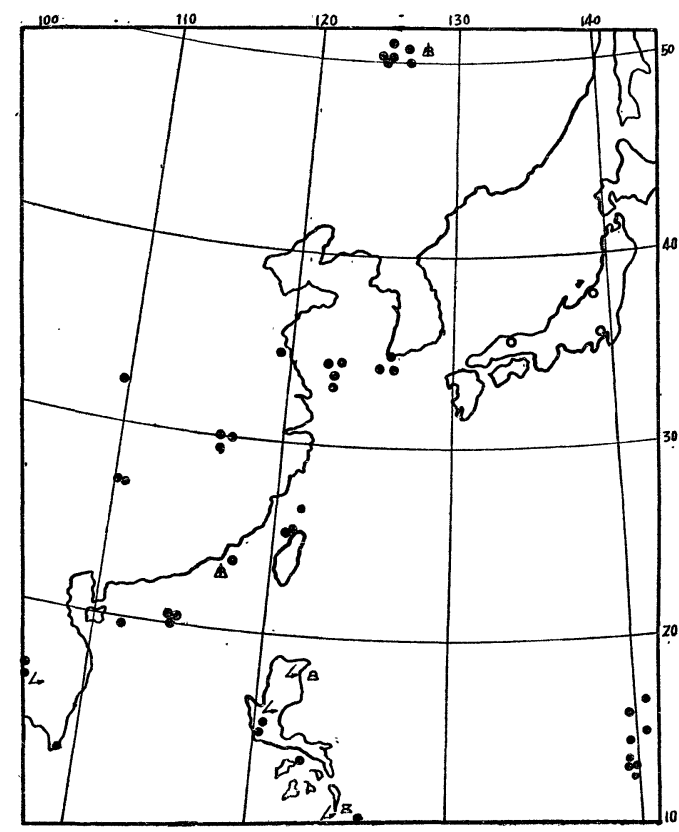

Fig. 1 Distribution of atmospherics sources, 2100, 12th, May, 1950

$\bigcirc$ represents observation points :

- represents intersection points: Lightnings and Cumulo-nimbus during the same time are shown.

City was not long enough, it was difficult to locate very remote atmospherics sources in the east or west of Japan.

In the 2nd and 3rd observation periods we extended the base lines, and could locate the sources in so far

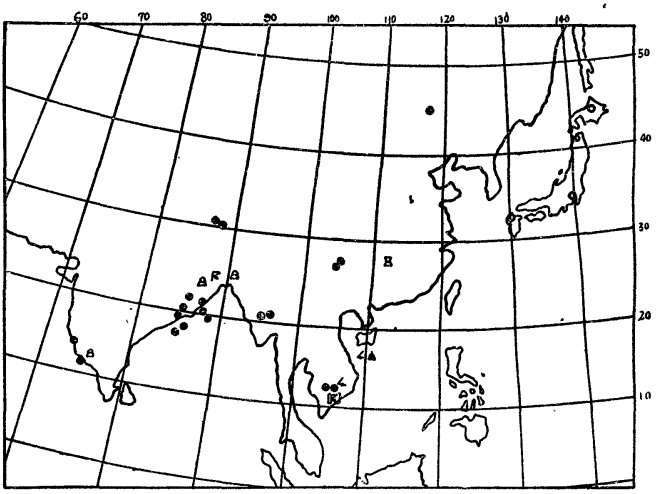

Fig. 2 Distribution of atmospherics sources, 2100, 24th, Sept., 1950

represents observtion points :

- represents intersection points : Lightnings and Cumulo-nimbus during the same time are shown.

regions as India. An instance is shown in Fig. 2.

In summer $60 \%$ of atmospherics sources are distributed in such tropical regions as Philippine Islands, Indo-china, Malay, Java, Sumatora, India, New Guinea, Australia etc. and in winter this percentage varies to $90 \%$. The remains of atmospherics sources are distributed over the temperate regions inciuding Japan. In any observation we scarcely find theatm ospherics sources in the region to the north of $60^{\circ} \mathrm{N}$ line. 
Atmospherics from the Tropical Regions

We have collected meteorological reports communicated from the tropical regions mentioned above.

We compiled the reports of lightnings observed during the same time as our atmospherics observation, and examined the existence of the intersection points which corresponded to the reports of lightnings.

The results are shown in the following table.

\begin{tabular}{|l|c|c|}
\hline \multicolumn{1}{|c|}{ Region } & $\begin{array}{c}\text { Number of Times When } \\
\text { Lightnings Were Reported }\end{array}$ & $\begin{array}{c}\text { Number of Times When Cor- } \\
\text { responding Points Existed }\end{array}$ \\
\hline The Philippine Island & 16 & 16 \\
\hline Indo-china, Malay & 9 & 9 \\
\hline India & 4 & 4 \\
\hline
\end{tabular}

When we compiled the reports of Cumulo-nimbus, the results are as follows:

\begin{tabular}{|l|c|c|}
\hline \multicolumn{1}{|c|}{ Region } & $\begin{array}{c}\text { Number of Times When } \\
\text { Cunb. Were Reported }\end{array}$ & $\begin{array}{c}\text { Nnmber of Times When Cor- } \\
\text { responding Points Existed }\end{array}$ \\
\hline The Philippine Islands & 8 & 2 \\
\hline Indo-china, Malay & 4 & 3 \\
\hline India & 2 & 2 \\
\hline
\end{tabular}

With these results we find the fact that in these remote regions atmospherics sources are always recorded on the vicinity where lightnings occur and that they are not always recorded when only Cumulo-nimbus are reported. Considering the spar. sity of the meteorological reports from these regions, it is probable that lightnings should exist when only Cumulo-nimbus are reported. Consequently we may conciude that the atmospherics observed to be in these remote regions are usually generated with lightnings.

\section{Atmospherics in the Temperate Regions}

We collected the results in which the atmospherics sources were observed to be concentrated in the temperate regions including Japan, and classified them by the districts. When we applied this method to the results of the 2nd observation period, we got the following table. The figures represent the number of atmospherics sources observed in 10 minutes, and the figures in the parentheses show their position by longitude and latitude. We also show the meteorological phenomena in the respective position with the following notations:
Low.-Depression
C.F.-Cold front
S.F.-Stagnant front
S.S.-Snow shower
T.-Thunderstorm
L.-Lightning
D.S.-Dust storm 


\begin{tabular}{|c|c|c|c|c|c|c|}
\hline Date & $\underset{\text { (J.S.T. })}{\text { Time }}$ & $\begin{array}{l}\text { Region Near the } \\
\text { Ogasawara Islands }\end{array}$ & $\begin{array}{r}\text { Region Ne } \\
\text { Hokkaido } \\
\text { Prefec }\end{array}$ & $\begin{array}{l}\text { West } \\
\text { Akita }\end{array}$ & \multicolumn{2}{|c|}{ Manchuria } \\
\hline 23 & 15 & $3\left(\begin{array}{l}145 \mathrm{E} \\
20-25 \mathrm{~N}\end{array}\right) 2\left(\begin{array}{l}140 \mathrm{E} \\
30 \mathrm{~N}\end{array}\right)$ Low & & & & \\
\hline 24 & 12 & $5\left(\begin{array}{l}140-145 \mathrm{E} \\
25 \mathrm{~N}\end{array}\right) \quad$ C.F. & $1\left(\begin{array}{l}138 \mathrm{E} \\
40 \mathrm{E}\end{array}\right)$ & Low & & \\
\hline "I & 15 & $4\left(\begin{array}{l}140-145 \mathrm{E} \\
28 \mathrm{~N}\end{array}\right) \quad$.C.F. & $6\left(\begin{array}{l}138 \mathrm{E} \\
38-40 \mathrm{~N}\end{array}\right)$ & Low & & \\
\hline "I & 21 & $2\left(\begin{array}{l}145 \mathrm{E} \\
32 \mathrm{~N}\end{array}\right)$ & & & & \\
\hline 25 & 12 & $4\left(\begin{array}{l}143 \mathrm{E} \\
25-30 \mathrm{~N}\end{array}\right) \quad$ C.F. & & & $11\left(\begin{array}{l}120-130 \mathrm{E} \\
45-50 \mathrm{~N}\end{array}\right)$ & Low \\
\hline " & 15 & $2\left(\begin{array}{l}143 \mathrm{E} \\
23 \mathrm{~N}\end{array}\right)$ & & & & \\
\hline 26 & 9 & $5\left(\begin{array}{l}143 \mathrm{E} \\
30 \mathrm{~N}\end{array}\right)$ & & & & \\
\hline " & 15 & $10\left(\begin{array}{l}140-145 \mathrm{E} \\
20-30 \mathrm{~N}\end{array}\right)$ & & & & \\
\hline "l & 21 & $3\left(\begin{array}{l}140-150 \mathrm{E} \\
30 \mathrm{~N}\end{array}\right)$ & & & & \\
\hline 27 & 15 & $4\left(\begin{array}{l}150 \mathrm{E} \\
30 \mathrm{~N}\end{array}\right)$ & $2\left(\begin{array}{l}140 \mathrm{E} \\
40 \mathrm{~N}\end{array}\right)$ & $\mathrm{T}$ & & \\
\hline 28 & 9 & $5\left(\begin{array}{l}140 \mathrm{E} \\
23-27 \mathrm{~N}\end{array}\right)$ & $3\left(\begin{array}{l}130 \mathrm{E} \\
43 \mathrm{~N}\end{array}\right)$ & $\mathrm{T}$ & & \\
\hline "I & 15 & $4\left(\begin{array}{l}138 \mathrm{E} \\
28 \mathrm{~N}\end{array}\right) 4\left(\begin{array}{l}143 \mathrm{E} \\
30 \mathrm{~N}\end{array}\right)$ & & & & \\
\hline 29 & 9 & $5\left(\begin{array}{l}140 \mathrm{E} \\
28-32 \mathrm{~N}\end{array}\right) \quad . \quad$ C.F. & $3\left(\begin{array}{l}140 \mathrm{E} \\
45 \mathrm{~N}\end{array}\right)$ & & & \\
\hline " & 12 & $10\left(\begin{array}{l}140-145 \mathrm{E} \\
30 \mathrm{~N}\end{array}\right)$ & $1\left(\begin{array}{l}140 \mathrm{E} \\
43 \mathrm{~N}\end{array}\right)$ & & & \\
\hline " & 15 & $8\left(\begin{array}{l}140-150 \mathrm{E} \\
28 \mathrm{~N}\end{array}\right)$ & $9\left(\begin{array}{l}142 \mathrm{E} \\
40-45 \mathrm{~N}\end{array}\right)$ & $\mathrm{T}$ & $2\left(\begin{array}{l}127 \mathrm{E} \\
40 \mathrm{~N}\end{array}\right)$ & C.F. \\
\hline "I & 21. & $1\left(\begin{array}{l}142 \mathrm{E} \\
30 \mathrm{~N}\end{array}\right)$ & $5\left(\begin{array}{l}145 \mathrm{E} \\
45 \mathrm{~N}\end{array}\right)$ & $\mathrm{T}$ & $3\left(\begin{array}{l}130 \mathrm{E} \\
40 \mathrm{~N}\end{array}\right)$ & C.F. \\
\hline
\end{tabular}

During the whole 2nd observation period, the cold fronts lay usually over the ocean in the south of Japan.

In such cases the atmospherics sources were observed to be concentrated in one or more points along them. When a cold front or a depression on frontal lines appeared in the south Manchuria area, the corresponding atmospherics sources were observed on 25th, 26th and 29th, Sept., 1950. The thunderstorm occurred in the west coast of Hokkaido when the frontal lines were passing on 27th, 28th and 29th, Sept., 1950. The corresponding atmospherics sources were observed distinctly. We can say that the depression and the frontal line do not always accompany the atmospherics but have a tendency to generate atmospherics when they arrive on some fixed regions. 
During the 3rd observation period we also got the following table.

\begin{tabular}{|c|c|c|c|c|c|}
\hline Date & $\begin{array}{c}\text { Time } \\
(\text { J.S.T. })\end{array}$ & $\begin{array}{l}\text { Region Near For- } \\
\text { mosa and Okinawa }\end{array}$ & $\begin{array}{l}\text { Region to the } \\
\text { North of Marcus }\end{array}$ & $\begin{array}{l}\text { Region to the } \\
\text { South of Kanto } \\
\text { District }\end{array}$ & $\begin{array}{l}\text { Coast of the } \\
\text { Japan Sea }\end{array}$ \\
\hline 13 & 9 & & & & $4\left(\begin{array}{l}135 \mathrm{E} \\
36 \mathrm{~N}\end{array}\right) \quad$ S.S. \\
\hline 14 & 15 & & $4\left(\begin{array}{l}150-155 \mathrm{E} \\
25-30 \mathrm{~N}\end{array}\right)$ C.F. & & \\
\hline 15 & 9 & & $4\left(\begin{array}{l}155 \mathrm{E} \\
25-30 \mathrm{~N}\end{array}\right) \quad$ C.F. & & \\
\hline ." & 12 & & $3\left(\begin{array}{l}145-150 \mathrm{E} \\
2530^{\circ} \mathrm{N}\end{array}\right) \quad$ C.F. & & \\
\hline 16 & 15 & $13\left(\begin{array}{l}125-130 \mathrm{E} \\
20-25 \mathrm{~N}\end{array}\right)$ Low & & & \\
\hline " & 21 & & $8\left(\begin{array}{c}155-160 \mathrm{E} \\
30-35 \mathrm{~N}\end{array}\right)$ Low & & \\
\hline 17 & 9 & & $6\left(\begin{array}{l}160-165 \mathrm{E} \\
25-30 \mathrm{~N}\end{array}\right)$ Low & & \\
\hline " & 12 & & $1\left(\begin{array}{l}160 \mathrm{E} \\
30 \mathrm{~N}\end{array}\right)$ & $4\left(\begin{array}{c}138 \mathrm{E} \\
33 \mathrm{~N}\end{array}\right) \quad$ S.F. & \\
\hline "I & 15 & $15\left(\frac{125-130 \mathrm{E}}{25-30 \mathrm{~N}}\right)$ T. D.S. & & $3\left(\begin{array}{l}138 \mathrm{E} \\
33 \mathrm{~N}\end{array}\right) \quad$ S.F. & \\
\hline "I & 21 & . & & $6\left(\begin{array}{l}138 \mathrm{E} \\
33 \mathrm{~N}\end{array}\right) \quad$ S.F. L. & \\
\hline 18 & 12 & $5\left(\begin{array}{l}135 \mathrm{E} \\
25 \mathrm{~N}\end{array}\right)$ & $3\left(\begin{array}{c}160 \mathrm{E} \\
30 \mathrm{~N}\end{array}\right) \quad$ Low & & \\
\hline 18 & 21 & & $4\left(\begin{array}{l}160 \mathrm{E} \\
30 \cdot 35 \mathrm{~N}\end{array}\right) \quad$ Low & & \\
\hline 19 & 12 & & & $3\left(\begin{array}{l}140 \mathrm{E} \\
35-38 \mathrm{~N}\end{array}\right)$ Low & \\
\hline
\end{tabular}

During this observation period a weak cold wave have happened, and brought snow showers in the coast of the Japan Sea from 12th to 14th, Jan., 1951. Atmospherics due to this shower were recorded in the observation as 0900 . Thunderstorms occurred twice during the night, one on 17th was caused by a stagnant front (Fig. 3) and the other on 19th by a depression. In both cases atmospherics were recorded at early part of the day.

In the region near Formosa and the Okinawa Islands many atmospherics sources were observed on 16th, 17th and 18th, Jan., 1951. This is the region where depressions are frequently generated. According to the weather map, a depression was actually generated on 16th, Jan., 1951. On 18th, Jan., 1951 the isobar did not close over this region but the wind distribution suggested that a cycionic disturbance might 
occur there. (Fig. 4). On 17th; Jan., 1951 the isobar showed no characteristic feature but thunderstorms and dust storms happened there during the night. (Fig. 3) We

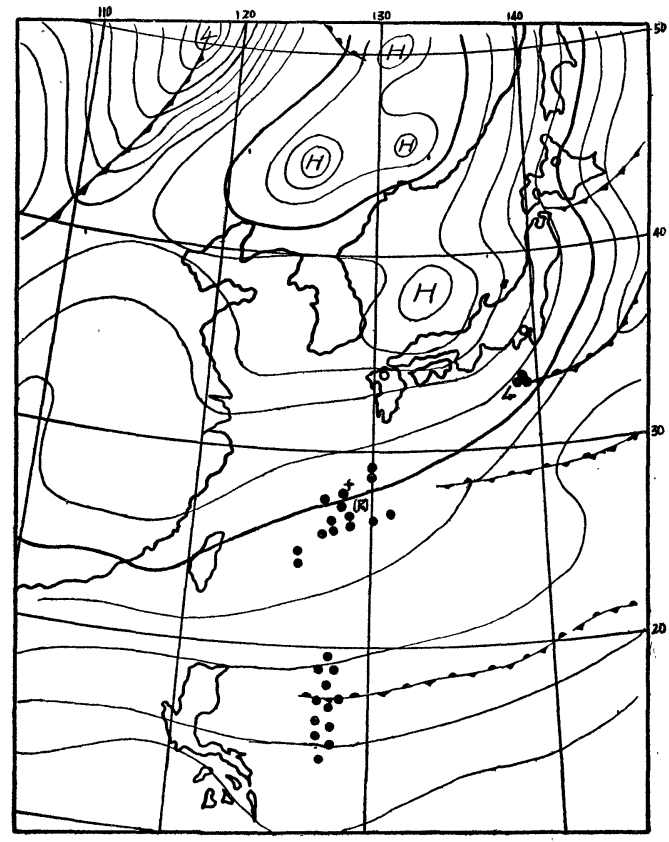

Fig. 3 Distribution of atmospherics sources and synoptic situation 1500, 17th, Jan., 1951. As for Lightnings and Dust storms, the one observed till 2100 are shown.

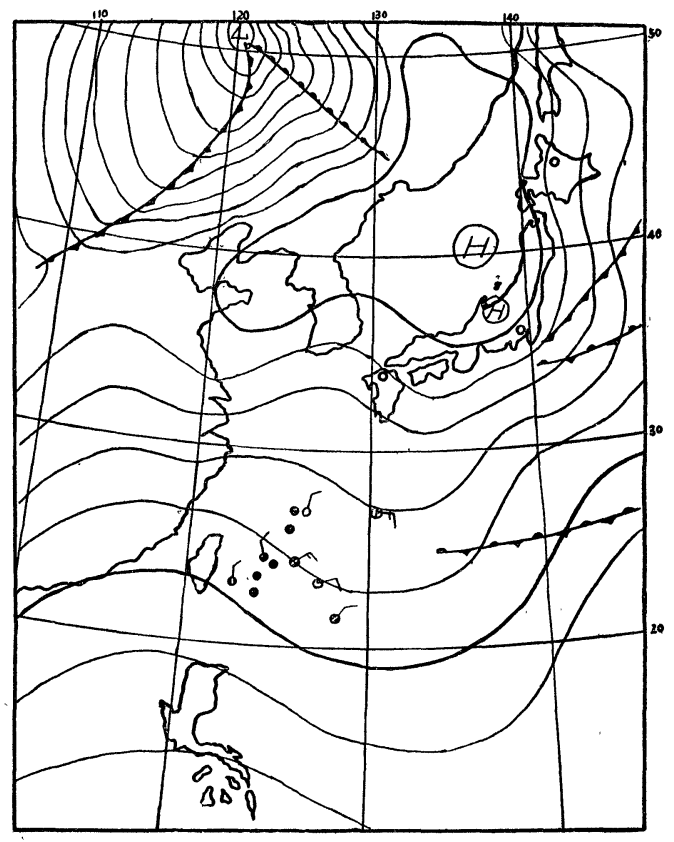

Fig. 4 Distribution of atmospherics sources and synoptic situation 1200, 18th, Jan., 1951. Wind distribution near atmospherics sources are shown.

observed also many atmospherics sources in the region to the north of Marcus Island 8 different times during this observation period. These sources always corresponded to a cold front or a depression on frontal lines. The distribution of the sources is very similar to the case observed in the region near the Ogasawara Islands in the 2nd observation period.

This region was a triple point, surrounded by Siberia, Okhotsk and Ogasawara air masses and was a field of cyclogenesis in that period. Consequentiy we consider that when depressions or frontal lines reached this region, they developed again and generated atmospherics.

\section{Atmospherics Accompanied with a Typhoon}

In the 1st observation period a typhoon appeared in the south-west Pacific Ocean and moved to the north taking the course illustrated in Fig. 5 . Atmospherics sources observed in its active area are shown in the following table.

\begin{tabular}{|c|c|c|c|}
\hline Date & $\begin{array}{c}\text { (J.S.T.) } \\
\text { Time }\end{array}$ & $\begin{array}{c}\text { Number of Atmospherics Sources } \\
\text { Observed in 10 Minutes }\end{array}$ & $\begin{array}{c}\text { Pressure of Center } \\
\text { of Typhoon in mb. }\end{array}$ \\
\hline 12 & 9 & 34 & 940 \\
\hline$\prime \prime$ & 12 & 10 & \\
\hline
\end{tabular}




\begin{tabular}{|c|c|c|c|}
\hline$\prime \prime$ & 15 & No Observation & 940 \\
\hline $1 "$ & 21 & 6 & \\
\hline 13 & 9 & No Observation & \\
\hline$\prime \prime$ & 12 & 12 & 940 \\
\hline$\prime \prime$ & 15 & No Observation & 950 \\
\hline$\prime \prime$ & 21 & 17 & \\
\hline 14 & 9 & 0 & 950 \\
\hline$\prime \prime$ & 12 & 4 & 960 \\
\hline$\prime \prime$ & 15 & No Observation & \\
\hline$\prime \prime$ & 21 & 0 \\
\hline
\end{tabular}

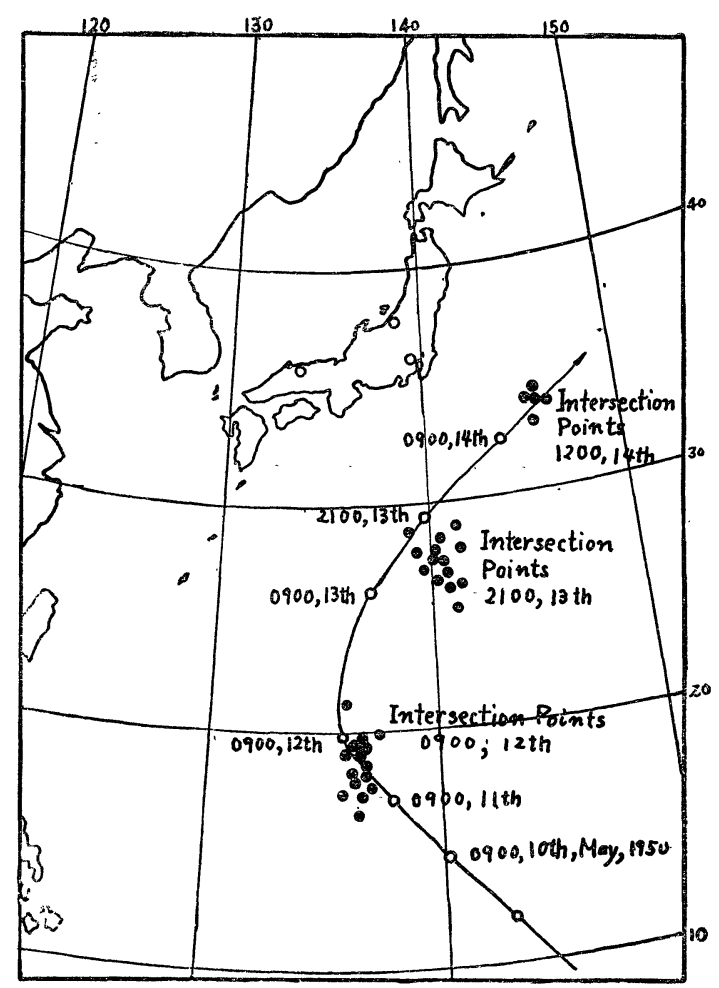

Fig. 5 Course of the typhoon DORIS and atmospherics sources observed in its active area.

- represents intersection points:

$O$ represents the centre of typhoon.
Acknowledgements

As the observation period was very short, the results, especialiy on the relation to meteorological phenomena, can be applied only to certain limited cases. But the atmospherics observa. tion stated in this paper may be useful to locate not only thunderstorms but also fronts, depressions or typhoons under some conditions. We will make further study on atmospherics in rela. tion to such meteorological phenomena.

The authors wish to express sincere thanks to many members of C.M.O.; especially to Mr. T. Furuhata, Mr.Z. Yanagisawa Mr. T. Suda for their help in the observation, and to Mr. S. Ooi for his help in the meteorological analysis.

\section{References}

(1) R.A. WATSON WATT and J.F. HERD : An Instantaneous Directreading Radio Goniometer. J.I.E. E. 641926611.

(2) W. STOFFEGEN: Distant Localization of Individual Atmospherics with a Cathode-ray Direction-finder of Unidirectional Type. Arkiv för Mathematik, Astronomi och Physik 34 A No. 26, 1948. 